\title{
Coca-Cola: The Most-Lawed Name
}

\section{PETER TAMONY}

\begin{abstract}
A
S he STANDS IN The STReets of Atlanta, Georgia, U.S.A., the chief executive of the Coca-Cola Company may say with Alexander, the Romans, and rulers of Spain, Holland, and Britain that the sun never sets on his empire - modern, twentieth century style. For the 1967 Report of his organization shows its drink downed 95 million times a day in 138 countries, and that for the first times sales exceeded one billion dollars.

The basis of this productive structure was formulated in $\mathbf{1 8 8 6}$ when John S. Pemberton, a Confederate veteran who had struggled through Reconstruction as a retail druggist, patent-medicine wholesaler, and vendor of a non-alcoholic drink, worked on yet another potable. During testing, after infusion of soda, at Willis Venable's fountain in Jacob's drug store at Five Points, comments and suggestions of patrons were considered, the consensus result being scripted Coca-Cola by F. M. Robinson, a penman-bookkeeper, who had been told the drink's taste was based in coca leaves and the kola nut.
\end{abstract}

Coca-Cola was first bottled by Joseph A. Biedenharn at Vicksburg in 1894. In 1899 Asa Chandler, who had bought the formula and business from Pemberton in 1888, gave two Chattanoogans, Ben Thomas and Joe Whitehead, a franchise in perpetuity for bottling the drink in most of the United States outside New England. Able merchandising and advertising, just after the turn of the century, stimulated national consumption of the beverage. Such fanfare and commercial success added myth and fantasy to the actual ingredients of the drink to the extent it early became a focus of controversy and remains so to food faddists and agitators to this day.

The alkaloid cocaine was first separated from the leaves of the shrub Erythroxylon coca by Wohler in 1860. For a decade or so it was considered a wonder stimulant and anesthetic, especially in England, where Arthur Conan Doyle, before he got wise, allowed 
Sherlock Holmes cocaine as a pick-me-up after a hard day's sleuthing. In the U.S. the use of cocaine appears to have been widespread in the South. By 1886, however, the drug was proclaimed "the worst slavery known," and advertisements of safe cures appeared in the press. Traditionally, an important article of commerce throughout Central Africa was the cola, kola or goora nut (Cola acuminata [Sterculiaceae]). From trees native to tropical Africa, numerous varieties of these nuts were used as stimulant condiments, all containing varying percentages of caffeine.

Such are the names in which the alliterative Coca-Cola is based. Whatever may have been the original formula of the drink, i.e., utilization of the decocainized leaf - the refuse product discarded in the manufacture of cocaine - and the cola nut for flavoring and stimulation, these seem to have been eliminated in the first decade of this century. Harvey W. Wiley, who was honored in 1956 by a U.S. postage stamp, in Beverages and Their Adulteration (1909), writes that the government, after seizing 40 barrels and 20 kegs of Coca-Cola, alleged that the merchandise as advertised by the company was misbranded in that it did not contain any coca or cola, and further that it was adulterated in that it did contain an added ingredient, caffeine, which was deleterious to health. After the usual legal hassel to the U.S. Supreme Court, the case was dismissed without prejudice, the company agreeing that its product would not be sold contrary to the provisions of the Federal Food and Drug Act, et cetera.

This was the decade during which the Pure Food and Drug Laws were being crusaded, Upton Sinclair's The Jungle (1906) and the writings of the muckrakers then characterizing American print. Wiley notes that the Report of the President's Homes Commission, appointed by Theodore Roosevelt, issued in 1908, listed about 50 beverages labeled with the words, coca cola, cola, coke, koke, and ola, in combinations, including Loco Kola.

It was to stem the flood of such imitations of its name, label and product, and to preserve its lucrative business, that the Coca-Cola Company went to law. The first of a 55 year series of suits, according to John J. Riley, appears to have been filed in 1912. This was against the Gay-Ola Co. of Memphis, Tennessee (200 Fed. 720; 119, C.C.A. 164). Gay-Ola was not among the brand names listed in the 1908 Report. Nor does this suit appear to have stemmed a 
rising tide of imitations. In January of 1916 five new cola drinks were named, the National Bottlers' Gazette appearing to endorse the concept that infusion of "and" between the words coca and cola could deseribe another's beverage without infringing the nationally known trademark.

Prior to passage of the Harrison Narcotics Law of 1914 many standard home remedies were liberally dashed with derivatives of opium, cocaine, et cetera, hop joint being a Southern allusion to a drug store. Among nineteenth-century assertions, Coca-Cola's first label claimed it "a valuable brain tonic and a cure for nervous afflictions - sick headache, neuralgia, hysteria, melancholy...." Service at soda fountains, a usual appendage of drug stores around the turn of the century, and word association with cocaine, engendered dope as a nickname of Coca-Cola. A variant was cold dope, while shot, or shot of dope, was employed, tonic being colloquial in New England. Coke is recorded in A Dictionary of Americanisms (1951), the first example of usage cited being from the Coca-Cola Bottler (Phila.), November 17, 1909. Priorly, the brand names Cola Coke and Koke Ola were listed in the 1908 Report of President Roosevelt's Commission. An impressive decision won by Coca-Cola was that against the Koke Company, terminated in 1920. In the finale, Justice Oliver Wendell Holmes held that Koke was an infringement on Coca-Cola's niokname, and described the plaintiff's beverage as "a single thing coming from a single source and well known in the community." J. H. Spingarn, writing in The Nation (June 7, 1941), notes that 143 beverages registered with the U.S. Patent Office used cola as an identity-form, and that the Coca-Cola Company had been filing a lawsuit a week for over 30 years to protect its trademark, nickname, et cetera. On the whole, such suits seem to have been calendared to sustain the image of CocaCola power, and to discourage small, granite-utensil mixologists. Such woodshed and basement entrepreneurs dotted towns and cities, supplying local saloons with sarsaparillas and carbonated mixtures for boozes prior to Prohibition, being wiped out in the 15-year eclipse of the poor man's club, by local sanitary and building codes, and costs of distribution. Further to terrorize competitors and their counsel, Coca-Cola's long-tentacled legal forces had Justice Holmes' pronunciamento buckrammed along with 700 pages of comparable decisions and injunctions for distribution to law libraries and attorneys. 
Such formidable authority, however, did not deter Charles G. Guth of New York, who was what Wall Street today would term a wheeler-dealer. As president of Loft, Inc., a chain of soda fountains and confectionaries, Guth thought he was entitled to a jobber's discount from Coca-Cola. In the tangle over refusal of this concession, Guth bought in bankruptcy proceedings, common during the Depression, the brand name and formula of Pepsi-Cola, an 1890's label listed in the 1908 Report of President Roosevelt's Commission. On losing a proxy battle in 1935, Guth pulled out of Loft, taking the Pepsi-Cola "property." In the court battle that ensued, a Chancery decree in Delaware awarded Guth most of the stock of the PepsiCola Corporation.

Pepsi-Cola became involved in the plethora of lawsuits generated by Coca-Cola to protect its business - charges of imitation of color, labeling a product cola, scripting the name of a competitive drink, service of other than Coca-Cola when a patron asked for a Coke, et cetera, such matters constituting deliberate and fraudulent attempts to appropriate its good-will, custom, and what-not. PepsiCola filed countersuits to restrain Coca-Cola from instituting harassing litigation, charging Coca-Cola had over the years attempted to exhaust the resources of competitors by nuisance lawing, and had thus bulldogged a monopoly by rushing to law. An example: to prosecute a suit in the Federal courts against a careless soda-jerk who had served another brand when asked for a Coke, Coca-Cola flew to San Francisco 18 executives and attorneys, including two representatives of Steve Hannigan's flash-fire public relations brigade. This had to be the world's-record-champion higher-ups air-hegira to December, 1940.

Finally, Pepsi-Cola, well heeled, took the offensive in the battle of the colas, filing registration of its trademark in Canada. In the legalese common to special pleaders, Coca-Cola had claimed the word cola was descriptive only of a nut which was unknown to the general public at the time its trademark was adopted, that it denominated a minor, unimportant constituent of the drink, and thus had no meaning in the beverage field except as part of its registered trademark. And that if cola did have another meaning it was because of the efforts of Coca-Cola, and the widespread advertisement of its trademark. Pepsi-Cola countered that no one could preempt usage of an English word, even if it had become common and cur- 
rent to describe a whole class of drinks. Considering, no doubt, the authority of a pillar of empire, Oxford English Dictionary, which records a 1795 example of usage in an Account of Sierra Leone, "Cola is a famous fruit, highly esteemed by the natives, to which they attribute the same virtues as to Peruvian bark," the Supreme Court of Canada declared the word cola a generic and descriptive term, which, as part of the common tongue, was open to anyone who wished to employ it as part of a trademark to indicate a type of beverage. On March 19, 1942 the Judicial Committee of the Privy Council, highest tribunal of the Empire, upheld the Canadian decision. Coincidentally, the very next day the Chancery Court of Delaware recorded a comparable decision in a suit involving the Nehi Corporation.

In April of 1942 Nehi took full-page magazine and newspaper space to tell the world "Court Decides in Favor of Royal Crown Cola." On June 8, 1942, Newsweel newsed a "Cola Armistice," recording that Coca-Cola and Pepsi-Cola, as a result of the London decision, had agreed to drop two suits in the U.S., and one or more in each of nearly 40 other countries.

Coca-Cola, however, retained its adjudicated right to the verbalism Coke. Perhaps forseeing the handwriting of the Canadian justices, it appears to have decided in 1941 to use the colloquial form of its name in its advertising. On the back cover of the Saturday Evening Post for January 10, 1942 an apple-cheeked pageboy with a bottle-top cap, wide-eyed, blazons, "Hello ... I'm 'CocaCola' known, too, as 'Coke'." A paragraph, headed "P.S.," succinctly outlines the word-clipping function of the American mind in its production of the caressive Coke, "the friendly abbreviation for the trade-mark 'Coca-Cola'." As our Armed Forces spread over the whole of the landed world during World War II, other peoples okayed the drink and the word as they became familiar with a second American universal, olcay.

Since 1942 the principal activity of the legal arm seems to be protection of the vocalism, "Coke." If the word is enunciated in an order, only Coca-Cola must be served. Apparently, a vendor, if he is one of the many old timers who will not sell Coca-Cola because of alleged aid to the Prohibitionists, must tell a customer he does not purvey Coke, and must get consent to a substitution. In an action entered in the U.S. District Court at San Francisco on October 16, 
1967, the defendant was "perpetually enjoined and restrained" in a consent decree in less than a month "from selling and supplying on calls for 'Coca-Cola' or 'Coke' any product other than the plaintiffs...."

As he touches his lips to the patented bottle (1915) for the "pause that refreshes" (1929) the Americano amazes the world. His mouth must ever be in action, smoking and chewing making a trilogy as the pause that refreshes becomes the pause that enriches Coca-Cola and all its competitors, plus the American Tobacco Company and Wrigley.

\section{SOURCES}

Federal Digest, Vol. 61A, Trade Marks and Trade Names and Unfair Competition. Coca-Cola; page of actions, 484 (St. Paul, Minn.: West Publishing Co., 1953). Fortune, December, 1938, pp. 64-67.

Life, June 23, 1952, p. 79.

Riley, John J. History of the American Soft Drink Industry, 1807-1957 (Washington, D.C.: American Bottlers of Carbonated Beverages, 1958), p. 234.

San Francisco Examiner, December 22, 1940, p. 4/2.

Scarborough, Dorothy. On the Trail of Negro Folk Songs (Cambridge: Harvard University Press, 1925), pp. 89-90: "The Hop Joint."

Shepard's Federal Reporter Citations. Fifth Edition, Supplement 1953-1965. CocaCola: one hundred forty actions (Colorado Springs, Colo., 1965).

Spingarn, J. H. "Of Coca, Cola, and the Courts." Nation, Vol. 152 (Jume 7, 1941), pp. 666-668.

Time, April 27, 1942, p. 41 (adv't, Nehi-Royal Crown Cola).

- - May 15, 1950, pp. 28-32 (cover article).

Wharton, Don. “Coca-Cola: Its Fame and Fortune." Reader's Digest, June, 1947, pp. 33-37.

Wiley, H. W. Beverages and Their Adulteration (Philadelphia: Blakiston, 1919), pp. 109-114; 405-408.

Also:

U.S. District Court for the Northern District of California, San Francisco: The Coca-Cola Company vs. Red Chimney, Inc., eto., Civil Action No. 48041, filed October 16, 1967. Plaintiff relies on trade-mark registrations: 22,046 issued January 31,$1893 ; 47,189$, October 31,$1905 ; 238,145$ and 238,146 , January 31,1928 , "CocaCola"; and 415,755, August 14, 1945, covering the trade-mark "Coke": all incontestible pursuant to the Lanham Trade-Mark Act.

General information: Coca-Cola is indexed in Reader's Guide to Periodical Literature (New York: Wilson), and New York Times Index. E. J. Kahn's The Big Drink, An Unofficial History of Coca-Cola (1960: New York, Random House), lacks an Index. Nor have I referred to Big Beverage, W. I. Campbell (1952: Atlanta, Tupper and Love), a novel, reviewed in New York Herald Tribune Book Review, November 9, $1952,14$. 